\title{
PENGADAAN TANAH BERDASARKAN UU. NO. 2 TAHUN 2012 TENTANG PENGADAAN TANAH BAGI PEMBANGUNAN UNTUK KEPENTINGAN UMUM (STUDI DI KABUPATEN CILACAP)
}

\author{
Budi Irawan \\ Magister Ilmu Hukum Fakultas Hukum Universitas Jenderal Soedirman
}

\begin{abstract}
The issuance of Law No. 2 of 2012 on land acquisition (land procurement law) as a legal basis for the government to be doing activities that require land development is expected to ensure legal certainty in land acquisition and sense of fairness to the parties affected by land acquisition. This study aims to analyze the provision of land for the construction of the public interest in Cilacap district and analyze the normative constraints encountered in land acquisition in Cilacap district by Act No. 2 of 2012. The method used is a normative juridical approach uses the method legisme legal positivism, which argues identical with the norms made written and promulgated by agencies or officials of the state. The acquisition of land for public purposes under Law No. 2 of 2012 in Cilacap district includes four (4) phases: Procurement Planning soil; Preparation of the Land Acquisition; Implementation of the Land Acquisition; Submission of Results. Form of compensation in land acquisition is in the form of money, in land, resettlement, ownership or other form approved by both parties. Normative constraints faced is the lack of synchronization and harmonization seen in the regulations implementing the land acquisition law is under preparation that implementation is set in Central Java governor regulation number 18 of 2013 which is about the team and the preparation of the study team. The existence of disharmony in the BAL procurement law is seen also at the time of submission of proof of rights to land at the disposal of land rights can not be contested in the future (Land Acquisition Act article 42 paragraph (2) and (3)), is not exactly.
\end{abstract}

Keyword: liability

\begin{abstract}
ABSTRAK
Terbitnya UU No. 2 Tahun 2012 tentang pengadaan tanah (UU pengadaan tanah) sebagai suatu landasan hukum bagi pemerintah yang akan melakukan kegiatan pembangunan yang memerlukan tanah diharapkan dapat menjamin kepastian hukum dalam perolehan tanah serta memenuhi rasa keadilan bagi pihak yang terkena pembebasan tanahnya. Penelitian ini bertujuan menganalisis pengadaan tanah untuk pembangunan bagi kepentingan umum dan menganalisis kendala normatif dalam pengadaan tanah di Kabupaten Cilacap berdasarkan UU. No. 2 Tahun 2012. Metode pendekatan yang digunakan yuridis normatif. Pengadaan tanah untuk kepentingan umum berdasarkan UU. No. 2 tahun 2012 mencakup: Perencanaan; Persiapan; Pelaksanaan Pengadaan Tanah; Penyerahan Hasil. Bentuk ganti kerugian dalam pengadaan tanah adalah uang, tanah pengganti, pemukiman kembali, kepemilikan saham atau bentuk lain yang disetujui oleh kedua belah pihak. Kendala normatif adalah tidak adanya sinkronisasi dan harmonisasi dalam peraturan pelaksanaan UU pengadaan tanah; tahap persiapan yang pelaksanaannya diatur dalam peraturan Gubernur Jawa Tengah No. 18 tahun 2013 yaitu tim persiapan dan tim kajian. Adanya ketidakharmonisan UU pengadaan dengan UUPA terlihat pada waktu penyerahan tanda bukti hak atas tanah pada saat pelepasan hak atas tanah yang tidak dapat diganggugugat dikemudian hari (UU pengadaan tanah Pasal 42 ayat (2) dan (3)), merupakan hal tidak tepat.
\end{abstract}

Kata kunci: pengadaan tanah, kepentingan umum, ganti rugi

\section{PENDAHULUAN}

Tanah mempunyai peranan penting dalam hidup dan kehidupan masyarakat diantaranya sebagai prasarana dalam bidang perindustrian, perumahan, jalan. Tanah dapat dinilai sebagai benda tetap yang dapat digunakan sebagai tabungan masa depan. Tanah merupakan tempat pemukiman dari sebagian besar umat manusia, 
disamping sebagai sumber penghidupan bagi manusia yang mencari nafkah melalui usaha pertanian dan perkebunan, yang akhirnya tanah juga yang dijadikan persemayaman terakhir bagi se-orang yang meninggal dunia. ${ }^{1}$

Semakin bertambahnya jumlah penduduk, akan bertambah pula kebutuhan akan tanah, tetapi hal ini tidak berbanding lurus dengan luasan tanah yang bersifat tetap. Akibatnya akan semakin sulit pula pengadaan tanah untuk pembangunan proyek pemerintah, karena setiap jengkal tanah sudah ada yang menguasai dan menggunakannya, disamping itu harga tanahpun semakin tinggi. Untuk itu diperlukan hukum tanah nasional yang dapat mengatur penyelenggaraan penggunaan tanah agar tercipta ketertiban dan menjamin kepastian hukum bagi setiap orang yang mempunyai hubungan hukum dengan tanah.

Pasal 33 Undang-undang Dasar Negara Republik Indonesia Tahun 1945 (UUD 1945) khususnya ayat (3). Pengertian "dikuasai” diuraikan lebih rinci dalam pasal 2 ayat (1) UUPA dinyatakan bahwa: Atas dasar ketentuan dalam Pasal 33 ayat (3) UUD 1945 dan hal-hal sebagaimana dimaksud Pasal 1, bumi, air dan ruang angkasa, termasuk kekayaan alam yang terkandung di dalamnya itu pada tingkatan tertinggi dikuasai oleh negara, sebagai organisasi kekuasaan seluruh rakyat.

Pasal 18 UUPA seakan mengingat-kan akan fungsi tanah yaitu fungsi sosial artinya apabila diperlukan untuk kepentingan umum, termasuk kepentingan bangsa dan negara serta kepentingan bersama dari rakyat, hak-hak atas tanah tersebut dapat dicabut, dengan memberi ganti kerugian yang layak dan menurut cara yang diatur oleh undang-undang. Hal-hal tentang pencabutan hak juga ditegaskan di dalam Pasal 1 Undang-undang nomor 20 tahun 1961 tentang pen-cabutan hak hak atas tanah dan bendabenda yang ada diatasnya.

Bila melihat Pasal 1 UU Nomor 20 Tahun 1961 dan Pasal 18 UUPA dapat diartikan pencabutan hak atas tanah merupakan jalan terakhir untuk memperoleh tanah dan benda-benda lainnya yang diperlukan untuk kepentingan umum. Dalam melakukan pencabutan hak-hak atas tanah tersebut kepentingan pemilik tidak boleh diabaikan. Selain kewenangan pemerintah untuk melakukan pencabutan hak diberikan pula jaminan ganti kerugian yang layak.

Pengadaan tanah untuk kepentingan umum merupakan kepentingan pembangunan juga haruslah memperhatikan suatu lokasi yang tentunya akan berimplikasi kepada pengadaan untuk tanah itu sendiri, di sisi lain tanah harus dipergunakan dan dimanfaatkan sebesar-besarnya untuk kesejahteraan rakyat secara adil dan merata, juga harus dijaga kelestariannya. ${ }^{2}$ Tanah merupakan salah satu sarana kebutuhan yang amat penting dalam pengadaan tanah untuk kepentingan umum tidaklah mudah untuk dipecahkan. $^{3}$

Tuntutan masyarakat akan perlakuan yang lebih adil mengenai tanah makin bertambah besar seiring dengan berakhirnya era orde baru yang berganti dengan era reformasi. Selama

\footnotetext{
Abdurrahman, 1983, Masalah Hak-Hak Atas Tanah dan Pembebasan Tanah di Indonesia, cet. 2, Alumni, Bandung, hal. 1.

2 Achmad Rubai, 2007, Hukum Pengadaan Tanah untuk Kepentingan Umum, Bayumedia Publishing, Malang, hal. 1.
} 3 I Wayan Suandra, 1994, Hukum Pertanahan Indonesia,
cet.1, PT.Rineke Cipta, Jakarta, hal.11 
kurang lebih dari enam belas tahun era reformasi berjalan di Indonesia segala bentuk pelanggaran-pelanggaran terhadap hukum dan hak asasi manusia terus diperbaiki. Munculnya Peraturan Presiden Nomor 36 Tahun 2005 tentang Pengadaan Tanah Bagi Pelaksanaan Pembangunan untuk Kepentingan Umum dan Peraturan Presiden Nomor 65 Tahun 2006 tentang Perubahan atas Peraturan Presiden Nomor 36 Tahun 2005 tentang Pengadaan Tanah Bagi Pelaksanaan Pembangunan untuk Kepentingan Umum, masih dianggap belum sesuai dengan prinsip yang ada di dalam Undang-undang Dasar Negara Republik Indonesia khususnya Pasal $28 \mathrm{H}$ ayat (4), Pasal 33 ayat (3) dan hukum tanah nasional. Disatu sisi, negara menjamin kepemilikan sah individu sebagaimana diamanatkan oleh UUD 1945 dan UUPA, disisi lain pelaksana kekuasaan negara yakni pemerintah berkewajiban menjalankan agenda pembangunan infrakstruktur fisik yang kerap kali mengorbankan nilai kepentingan individu artinya saat dibutuhkan demi kepentingan umum, kepentingan individu bisa dikompromikan, bahkan dikalahkan dan hak milik atas tanah harus dilepaskan.

Salah satu upaya untuk mencapai tujuan tersebut adalah melalui pembangunan oleh negara atau pemerintah. Pembangunan yang dilakukan pemerintah dewasa ini antara lain pemenuhan kebutuhan pengadaan tanah untuk kepentingan umum, yang harus didukung oleh peraturan perundang-undangannya. Pembentukan peraturan perundangun-dangan memerlukan pendekatan yang mencerminkan pola pikir yang proaktif yang dilandasi sikap kritis dan obyektif. ${ }^{4} \mathrm{Hal}$ ini guna mewujudkan cita-cita yang luhur bangsa Indonesia, untuk itu diperlukan komitmen pembuat peraturan perundang-undangan yang sungguh-sungguh untuk memberikan dasar dan arah yang adil dalam pengelolaan sumber daya alam berkelanjutan dan ramah lingkungan dengan tidak menyengsarakan masyarakat, sehingga adanya keseimbangan antara kepentingan pemerintah dan kebutuhan masyarakat.

Dari sekian banyak asas haruslah asas keadilan diutamakan karena asas ini telah ditegaskan dua kali pada ketentuan umum pasal 1 angka 2 dan angka 10 Undang-undang ini. Metode pendekatan yang digunakan adalah yuridis normatif. Spesifikasi penelitian ini adalah deskriptif, yaitu suatu penelitian yang menggambarkan keadaan obyek yang akan diteliti. ${ }^{5}$ Bahan hukum yang digunakan dalam penelitian ini terdiri dari bahan hukum primer dan bahan hukum sekunder. Bahan Hukum yang diperoleh akan dianalisis secara normatif yang dilakukan konstruksi hukum untuk menjawab suatu isu hukum dengan proses analogi, argument a contrario, penyempitan makna hukum (recht verfijning $)^{6}$

\section{PEMBAHASAN}

Pengadaan Tanah untuk Kepentingan Umum berdasarkan Undang-Undang Nomor 2 Tahun

\section{2 di Kabupaten Cilacap.}

Pasal 33 ayat (3) UUD 1945, menentukan bahwa penggunaan tanah bumi, air, dan kekayaan alam yang terkandung di dalamnya oleh negara dipersyaratkan untuk dipergunakan bagi sebesar-besarnya kemakmuran rakyat. Secara yuridis, kepentingan mencapai sebesar-besar-

4 Maria S.W.Sumardjono, 2001, Kebijakan Pertanahan Antara Regulasi Dan Implementasi, Penerbit Buku Kompas, hal 1

Ronny Hanintijo Sumitro, 1988, Metodologi Penelitian Hukum, Ghalia Indonesia, Jakarta, hal.16.

6 Suratman dan H.Philips Dillah, Op cit., hal. 86. 
nya kemakmuran rakyat merupakan dasar dikuasainya tanah oleh negara. Negara memiliki kekuasaan atas tanah dalam arti negara mempunyai kewenangan untuk mengatur semua hubungan hukum atas tanah agar berbagai dimensi kebutuhan masyarakat secara perorangan maupun kelompok terpenuhi.

Pasal 6 UUPA dimuat suatu pernyataan penting mengenai hak-hak atas tanah, yang merumuskan secara singkat sifat kebersamaan atau kemasyarakatan hak-hak atas tanah menurut konsepsi yang mendasari hukum tanah nasional. Pasal 6 tersebut bunyinya sebagai berikut: Semua hak atas tanah mempunyai fungsi sosial.

Fungsi sosial hak-hak atas tanah mewajibkan pada yang mempunyai hak untuk mempergunakan tanah yang bersangkutan sesuai dengan keadaannya, artinya: keadaan tanahnya, serta sifat dan tujuan pemberian haknya. Jika kewajiban itu sengaja diabaikan maka hal tersebut dapat mengakibatkan hapusnya atau batalnya hak yang bersangkutan. Dalam hal yang demikian tanah termasuk golongan yang “ditelantarkan" (Penjelasan Pasal 27 UUPA).

Jika tanah hak milik, hak guna usaha, tanah hak guna bangunan ditelantarkan, haknya akan hapus dan tanah yang bersangkutan jatuh pada negara, artinya menjadi tanah negara kembali (pasal 27 ayat 3 , pasal 34 huruf e dan pasal 40 huruf e UUPA). Ketentuan ini sesuai dengan peraturan yang berlaku dalam hukum adat. Sifat dan tujuan pemberian Hak guna bangunan adalah, bahwa yang empunya hak akan membangun rumah atau bangunan lain di atas tanahnya. Kalau tanahnya dibiarkan kosong tanpa alasan, maka yang de-mikian itu termasuk dalam pengerti-an "ditelantarkan".
Adapun fungsi sosial hak-hak atas tanah berarti, bahwa tanah juga bukan komoditi perdagangan, biarpun dimungkinkan tanah yang dipunyai dijual, jika ada keperluan. Penyediaan tanah oleh perusahaan Kawasan Industri menurut Keputusan Presiden No. 53 Tahun 1989 tentang "Kawasan Industri" dan penyediaan tanah oleh apa yang disebut Kawasan Siap Bangun, menurut UU No. 4 Tahun 1992 tentang "Perumahan dan Pemukiman", bukan kegiatan perdagangan tanah, melainkan usaha untuk mempermudah perusahaan-perusahaan industri dan perusahaan-perusahaan pembangunan perumahan dalam memperoleh tanah yang diperlukan, termasuk prasarana dan sarana.

Kepentingan umum harus diutamakan daripada kepentingan pribadi, sesuai dengan asas hukum yang berlaku bagi terselenggaranya berkehidupan bersama dalam masyarakat. Tetapi biarpun demikian ke-pentingan individu juga tidak diabaikan, karena seperti yang telah dikemukakan di atas, hak individu atas tanah dihormati dan dilindungi oleh hukum. Maka jika kepentingan umum menghendaki didesaknya kepentingan individu, hingga yang terakhir ini mengalami kerugian, maka kepadanya harus diberikan pengganti kerugian. UU No. 26 Tahun 2007 tentang Penataan Ruang, LN 200768 ada ketentuan dalam Pasal 61a, bahwa "Setiap orang berkewajiban menaati rencana tata ruang yang telah ditetapkan". Tetapi kalau kegiatan pembangunan yang dilaksanakan sesuai dengan rencana tata ruang yang telah ditetapkan itu, mengakibatkan kerugian bagi seseorang yang mempunyai tanah, ia berhak memperoleh penggantian yang layak sesuai ketentuan Pasal 60c. Menurut Pasal 18 Undang-Undang Pokok Agraria maka untuk kepentingan umum, termasuk untuk kepentingan bangsa dan negara serta ke- 
pentingan bersama dari rakyat, hak-hak atas tanah dapat dicabut dengan memberikan ganti rugi yang layak dan menurut cara yang diatur oleh undang-undang yaitu Undang-undang Nomor 20 Tahun 1961 tentang Pencabutan Hakhak Atas Tanah dan Benda-benda yang Ada di Atasnya.

Berdasarkan prinsip Hak Menguasai $\mathrm{Ne}$ gara sebagaimana ditentukan dalam Pasal 33 ayat (3) UUD 1945 jo Pasal 2 UUPA UUPA dan prinsp fungsi hak atas tanah sebagaimana yang ditentukan dala Pasal 6 UUPA, maka pengadaan tanah bagi pembangunan untuk kepentingan umum dapat dilaksanakan asalkan sesuai dengan prinsip dasar pembangunan yaitu untuk mewujudkan masyarakat yang adil, makmur dan sejahtera. Hal tersebut penerapannya melalui UU pengadaan tanah yaitu UU No. 2 tahun 2012 tentang pengadaan tanah bagi pembangunan untuk kepentingan umum. Mekanisme pengadaan tanah bagi pembangunan untuk kepentingan umum yang dahulu diatur melalui Keputusan Presiden Nomor 55 Tahun 1993 tentang Pengadaan Tanah Bagi Pelaksanaan Pembangunan untuk Kepentingan Umum yang dikemudian diubah dengan Peraturan Presiden 36 Tahun 2005 jo Peraturan Presiden Nomor 65 Tahun 2006 yang salah satu pasalnya menerapkan "pencabutan hak" sudah tidak berlaku lagi. Mekanisme pengadaan tanah untuk kepentingan umum saat ini mengacu pada UU pengadaan tanah dengan menghilangkan pasal "pencabutan hak", karena pencabutan hak pun telah diatur tersendiri dalam undang-undang nomor 20 tahun 1961 yaitu tentang pencabutan hak-hak atas tanah dan benda-benda yang ada di atasnya.
Menurut Abdulrachman untuk terlaksananya suatu pencabutan hak atas tanah untuk kepentingan umum harus dipenuhi adanya beberapa persyaratan yaitu:

1. Pencabutan hak hanya dapat dilakukan bilamana kepentingan umum benarbenar menghendakinya. Unsur kepentingan umum harus tegas menjadi dasar dalam pencabutan hak ini. Termasuk dalam pengertian kepentingan umum ini adalah kepentingan bangsa, negara, kepentingan bersama dari rakyat, serta kepentingan pembangunan.

2. Pencabutan hak hanya dapat dilakukan oleh pihak yang berwenang menurut tata cara yang ditentu dalam ketentuan perundangan yang berlaku. Untuk keperluan itu Pemerintah telah menetapakan Undangundang Nomor 20 tahun 1961 dan berbagai ketentuan pelaksanaannya guna mengatur acara pencabutan hak atas tanah tersebut.

3. Pencabutan hak atas tanah harus disertai dengan ganti kerugian yang layak. Siempunya hak atas tanah berhak atas pembayaran sejumlah ganti kerugian yang layak berdasarkan atas harga yang pantas. $^{7}$

Bilamana pencabutan hak tersebut tanpa mengindahkan, persyaratan-persyaratan dimaksud, maka perbuatan yang dilakukan oleh pihak pemerintah dapat dinilai sebagai suatu perbuatan pemerintah yang melanggar hukum (onrechmatigeoverheidsdaad atau sebagai penyalahgunaan wewenang).

Syarat pertama yang harus diindahkan dalam melaksanakan pencabutan hak harus dilakukan benar-benar untuk kepentingan umum. Pasal 18 UUPA yang merupakan dasar untuk mengadakan tindakan ini menyebutkan adanya kepentingan umum sebagai dasar mengadakan pencabutan hak dan memasukkan ke dalamnya kepentingan bangsa dan negara serta kepentingan bersama dari rakyat, kemudian oleh

7 Abdurrahman, Op. Cit, hal.39 
UU No. 20 Tahun 1961 ditambahkan pula dengan memasukkan kedalamnya adanya kepentingan pembangunan. Oleh karena itu maka pencabutan hak atas tanah tetap diberlakukan walaupun di dalam UU pengadaan tanah pencambutan hak tidak dicantumkan.

Ada tiga prinsip suatu kegiatan pembangunan dapat dikatakan kepentingan umum, yaitu:

1. Kegiatan tersebut benar-benar dimiliki pemerintah

Prinsip ini mengandung batasan bahwa kegiatan kepentingan umum tidak dapat dimiliki oleh perorangan ataupun swas-ta. Dengan kata lain perorang-an dan swasta tidak dapat memiliki jenis-jenis kegiatan ke-pentingan umum yang membutuhkan pembebasan tanah-tanah hak maupun swasta.

2. Kegiatan pembangunan terkait dilakukan oleh pemerintah

Prinsip ini memberikan batasan bahwa proses pelaksanaan dan pengelolaan suatu kegiatan untuk kepentingan umum hanya dapat diperankan oleh pemerintah. Tetapi dalam praktiknya pengelolaan kegiatan untuk kepentingan umum tersebut ditenderkan oleh pihak swasta, contohnya kegiatan pembangunan waduk kedung ombo.

3. Kegiatan tersebut tidak mencari keuntungan

Prinsip ini membatasi tentang fungsi suatu kegiatan untuk kepentingan umum sehingga benar-benar berbeda dengan kepentingan swasta yang bertujuan untuk mencari keuntungan. ${ }^{8}$

Pada zaman Orde Baru banyak dilakukan pembebasan hak atas tanah, karena lebih mengutamakan pembangunan ekonomi untuk pertumbuhan dan merangsang investasi. Agar semuanya itu terwujud, sering diambil kebijaksanaan yang kadang-kadang bertentangan dengan hukum yang berlaku. Misal: terjadinya penguasaan tanah secara besar-besaran, pembe-

Op cit., hal. 76

Eddy Ruchiyat, 1999, Politik Pertanahan Nasional Sampai Orde Reformasi. Penerbit PT. Alumni. Bandung, hal.110 basan tanah yang tidak dengan ketentuan hukum dan lain sebagainya. ${ }^{9}$

Dari hasil penelitian dapat dideskripsikan bahwa untuk mendapatkan tanah dalam pengadaan tanah bagi pembangunan untuk kepentingan umum melalui 4 (empat) tahapan yang diatur di dalam Pasal 13 UU pengadaan tanah.Pengadaan tanah bagi pembangunan untuk kepentingan umum oleh Pemerintah, Pemerintah Daerah, Badan Usaha Milik Negara dan Badan Usaha Milik Daerah dilaksanakan dengan beberapa tahapan: perencanaan: $\mathrm{Pe}$ rsiapan; pelaksanaan; penyerahan hasil.

Dalam melaksanakan kegiatan apapun diperlukan suatu perencanaan yang matang dan komprehensif serta berkelanjutan, begitu pula dengan pemerintah, pemerintah daerah, badan usaha milik negara dan badan usaha milik daerah dalam instansi yang memerlukan tanah untuk pembangunan untuk kepentingan umum. Mengingat konsep pembangunan Indonesia pada dasarnya menggunakan konsep pembangunan berkelanjutan. Pembangunan yang berkelanjutan merupakan standar yang tidak hanya ditujukan bagi perlindungan lingkungan, ${ }^{10}$ melainkan juga bagi kebijakan pembangunan artinya dalam penyediaan, penggunaan, peningkatan kemampuan sumber daya alam dan peningkatan taraf ekonomi, perlu menyadari pentingnya pelestarian fungsi lingkungan hidup, kesamaan derajat antar generasi, kesadaran akan hak dan kewajiban masyarakat, pencegahan terhadap pembangunan yang merusak dan tidak bertanggung jawab terhadap lingkungan serta kewajiban untuk turut serta dalam

10 Koesnadi Hardjasoemantri, 1999, Hukum Tata Lingkungan, Gajah Mada University Press, Yogyakarta, hal 18-19. 
melaksanakan pembangunan berkelanjutan pada setiap lapisan masyarakat.

Dokumen Perencanaan pengadaan tanah yang disusun oleh instansi yang memerlukan tanah, dapat pula disusun secara bersama-sama oleh instansi tekhnis terkait atau dapat pula dibantu oleh lembaga professsional yang ditunjuk oleh instansi yang memerlukan tanah. Dokumen perencanaan ini haruslah ditetapkan terlebih dahulu sebelum diserahkan kepada pemerintah provinsi atau gubernur (Pasal 15 ayat (3) UU pengadaan tanah).

Untuk pihak yang berhak dan obyek pengadaan tanah merupakan masyarakat hukum disamping keberadaannya diakui setelah dilaksanakan penelitian dan ditetapkan dengan peraturan daerah setempat, juga harus memenuhi persyaratan sebagai berikut:

a. Terdapat sekelompok orang yang masih terikat hukum adatnya sebagai warga bersama suatu persekutuan hukum adat tertentu, yang mengakui dan menerapkan ketentuan persekutuan tersebut dalam kehidupannya seharihari

b. Terdapat tanah ulayat tertentu yang menjadi lingkungan hidup para warga persekutuan hukum adat tersebut dan tempatnya mengambil keperluan hidupnya sehari-hari

c. Terdapat tatanan hukum adat mengenai pengurusan, penguasaan dan penggunaan tanah ulayat yang berlaku dan ditaati oleh para warga persekutuan hukum adat tersebut.

Ganti kerugian di dalam pengadaan tanah bukan saja berupa kepada pemegang atas tanah pihak yang berhak tetapi juga kepada pemilik bangunan, tanaman atau benda lain yang berkaitan dengan tanah (pasal 17 ayat (2) huruf $h$ Perpres nomor 71 tahun 2012). Pihak yang berhak atas obyek pengadaan tanah berupa bangunan, tanaman atau benda lain yang berkaitan dengan tanah bisa perorangan, badan hukum, badan hukum sosial, badan keagamaan atau instansi pemerintah yang memiliki cukup bukti adanya penguasaannya. Pembuktian pemilikan tersebut dibuktikan dengan alat bukti:

a. Izin mendirikan bangunan dan bukti fisik bangunan

b. Surat pernyataan penguasaan fisik

c. Bukti tagihan atau pembayaran listrik, telepon atau perusahaan air minum dalam 1 (satu) bulan terakhir.

Dalam hal pembuktian dari para pihak atas obyek pengadaan tanah tidak ada, pembuktian pemilikan atau penguasaan dapat dilakukan dengan bukti lain berupa pernyataan tertulis dari yang bersangkutan dan keterangan yang dapat dipercaya dari 2 (dua) orang saksi dari lingkungan setempat yang tidak mempunyai hubungan keluarga dengan yang bersangkutan sampai derajat kedua, baik dalam kekerabatan vertikal maupun horizontal, yang menyatakan bahwa yang bersangkutan adalah benar sebagai pemilik atau menguasai sebidang tanah tersebut.

Kegiatan persiapan pengadaan tanah berupa konsultasi publik adalah suatu kegiatan yang sangat menentukan apakah rencana pembangunan kepentingan umum oleh instansi yang membutuhkan diterima atau ditolak oleh masyarakat, apabila dalam konsultasi publik ditolak oleh masyarakat ataupun masih adanya pihakpihak yang keberatan atas lokasi ren-cana pembangunan, instansi yang memerlukan tanah melaporkan segera keberatan dimaksud kepada Gubernur setempat. Gubernur selaku pemangku wilayah yang akan menetapkan penetapan lokasi membentuk tim untuk melakukan kajian atas keberatan oleh masyarakat atas lokasi rencana pembangunan untuk kepentingan umum.

Kantor Pertanahan Kabupaten Cilacap dalam melaksanakan tahapan pelaksanaan 
pengadaan tanah bagi pembangunan untuk kepentingan umum yaitu pengadaan tanah pembangunan sutet di wilayah Kabupaten Cilacap oleh PT. PLN (persero), mendapat mandat dari Kepala kantor wilayah badan pertanahan nasional provinsi jawa tengah dengan surat keputusan tanggal 9 Juli 2013 nomor 3394 / KEP33 /VII / 2013. Sebelum melaksanakan tugasnya, kepala kantor pertanahan kabupaten cilacap membentuk susunan pelaksana tugas pengadaan tanah untuk pembangunan sutet dengan surat keputusan kepala kantor pertanahan kabupaten cilacap tanggal 12 September 2013 Nomor 4806 / Kep.33.01 / IX / 2013

Dalam tahap persiapan pelaksanaan, kepala kantor pertanahan kabupaten cilacap selaku ketua pelaksana pengadaan tanah membentuk satuan tugas A dan satuan tugas B. Satuan tugas A membidangi inventarisasi dan identifikasi data fisik penguasaan tanah, pemilikan, penggunaan dan pemanfaatan tanah. Satuan tugas B membidangi inventtarisasi dan identifikasi data yuridis yang berhak dan obyek pengadaan tanah (Pasal 7 Perkaban nomor 5 Tahun 2012). Sebelum inventarisasi dan identifikasi dilaksanakan ketua pelaksana pengadaan tanah dan satgas $A$ dan satgas $B$ melakukan pemberitahuan kepada yang berhak melalui lurah/kepala desa atau nama lain. Pemberitahuan disampaikan secara langsung dengan cara sosialisasi, tatap muka atau surat pemberitahuan (Pasal 9 Perkaban Nomor 5 Tahun 2012).

Tahapan selanjutnya dalam pelaksanaan adalah menetapkan penilai harga kerugian tanah. Pasal 20 ayat (1) Perkaban Nomor 5 Tahun 2012 menentukan:

"Ketua pelaksana pengadaan tanah menetapkan penilai sesuai dengan ketentuan peraturan perundang-undangan".

Pengadaan jasa penilai dilakukan secara sederhana atau seleksi umum dengan jangka waktu paling lama 30 (tiga puluh) hari kerja. Apabila dalam jangka waktu yang telah ditentukan, seleksi penilai gagal atau tidak dapat terlaksana, ketua pelaksana menunjuk penilai publik yang merupakan penilai pemerintah yang sudah ditetapkan dan memperoleh izin dari menteri keuangan untuk memberikan jasa penilaian (Pasal 21 Perkaban Nomor 5 Tahun 2012).

\section{Kendala Normatif Yang Dihadapi Dalam Pe- ngadaan Tanah berdasarkan Undang-undang} Nomor 2 Tahun 2012 di Kabupaten Cilacap

Ketentuan Umum angka 2 dan angka 10 undangundang ini. Kalimat: "Ganti kerugian adalah penggantian layak dan adil" belum pernah muncul pada peraturan perundang-undangan yang mengatur tentang pengadaan tanah sebelumnya. Dengan mengatasnamakan pembangunan dan kepentingan umum maka setiap warga negara siap-siap untuk berpindah dari tanah yang ditempatinya. Padahal ganti kerugian dapat disebut adil, apabila keadaan setelah adanya pengambilalihan paling tidak setara dengan keadaan sebelumnya, di samping itu ada jaminan terhadap kelangsungan hidup mereka yang tergusur. ${ }^{11}$

Pihak yang berhak lebih memilih bentuk ganti kerugian berupa uang dibandingkan dengan bentuk ganti kerugian lainnya seperti pemukiman kembali, saham dan lain-lain. Hal tersebut dikarenakan besarnya ganti kerugian berupa uang sejumlah Rp 300.000,- per meter

${ }^{11}$ Loc. cit Maria S.W Sumardjono hal.89 
persegi adalah bukan merupakan ganti kerugian tetapi merupakan ganti keuntungan bila dilihat dari harga nilai jual obyek pajak yang hanya $R p$ 20.000,- per meter persegi atau dengan nilai pasar yang hanya Rp 150.000,- per meter persegi.

Bersamaan dengan pembayaran ganti kerugian dalam pengadaan tanah yang dilaksanakan langsung oleh PT. PLN kepada yang berhak, dibuatkan pelepasan hak atas tanah dan pemutusan hubungan hukum antara pihak yang berhak terhadap tanahnya. Di dalam Pasal 5 UU pengadaan tanah menegaskan pihak yang berhak wajib melepaskan tanahnya pada saat pelaksanaan Pengadaan Tanah untuk Kepentingan Umum setelah pemberian Ganti Kerugian atau berdasarkan putusan pengadilan yang telah memperoleh kekuatan hukum tetap. Kata wajib ditegaskan pada undang-gundang ini. Seharusnya ada keseimbangan hukum yaitu bahwa wajib setelah pemberian ganti kerugian dirasakan adil dan layak oleh pihak yang berhak. ${ }^{12}$

Bila dilihat Pasal 41 ayat (2) dan ayat (3) tersebut di atas yang menyatakan bahwa pihak yang berhak harus menyerahkan bukti penguasaan atau kepemilikan yang merupakan satusatunya bukti yang sah menurut hukum dan tidak dapat diganggu gugat di kemudian hari, hal ini dapat menjadi kendala dan mencerminkan Undang-undang ini represif. Kendala tersebut terdapat dalam kalimat "tidak dapat diganggu gugat di kemudian hari" ini bertentangan dengan fakta hukum yang sedang berlangsung di Indonesia yaitu dalam hal ini Pasal 19 ayat 2 Undang-Undang Nomor 5 Tahun 1960 tentang Peraturan Dasar Pokok-pokok Agraria.
Pemerintah yang menerbitkan sertifikat hak atas tanah tidak pernah menjamin sepenuhnya bahwa sertipikat itu tidak dapat digugat di kemudian hari, bagaimana mungkin pemilik tanah yang tanahnya terkena pengadaan tanah dan wajib diserahkan bagi pembangunan untuk kepentingan umum menjamin sertifikat yang diserahkan itu tidak dapat diganggu gugat di kemudian hari.

Kendala normatif lainnya Pasal 43 UU pengadaan tanah menyatakan: Pada saat pelaksanaan pemberian ganti kerugian dan pelepasan hak sebagaimana dimaksud dalam Pasal 41 ayat (2) huruf a telah dilaksanakan atau pemberian Ganti Kerugian sudah dititipkan di pengadilan negeri sebagaimana dimaksud dalam Pasal 42 ayat (1), kepemilikan atau Hak Atas Tanah dari Pihak yang Berhak menjadi hapus dan alat bukti haknya dinyatakan tidak berlaku dan tanahnya menjadi tanah yang dikuasai langsung oleh negara.

Adanya beberapa perubahan yang positif dalam ganti kerugian dalam pengadaan tanah bagi pembangunan untuk kepentingan umum yang diatur dalam UU pengadaan tanah dengan peraturan-peraturan sebelumnya. Perubahan lainya adalah mekanisme musyawarah dalam pengadaan tanah bukan terhadap nilai ganti kerugian tetapi yang ditawarkan adalah bentuk ganti kerugiannya. Perubahan ini diharapkan mampu melindungi hak-hak dari pemegang hak atas tanah yang tanahnya akan diperuntukan bagi pelaksanaan pembangunan untuk kepentingan umum. Pemerintah tidak dapat melakukan pemaksaan dengan mengatas-namakan kepentingan umum terhadap pemegang hak atas tanah agar bersedia melepaskan haknya suka atau 
tidak suka karena prinsip yang dipergunakan dalam UU pengadaan tanah yaitu kegiatan menyediakan tanah dengan cara memberi ganti kerugian yang layak dan adil kepada yang berhak serta penghormatan terhadap hak atas tanah. Oleh karena itu, pemerintah mengadakan perubahan-perubahan yang dianggap lebih memenuhi rasa keadilan dan lebih mencerminkan penghormatan terhadap hak asasi manusia.

\section{PENUTUP}

\section{Simpulan}

Jangka waktu tanggal penetapan lokasi dengan tanggal pengumuman yang berselang 13 (tiga belas) hari kerja, sehingga tidak sesuai dengan UU pengadaan tanah, padahal menurut UU pengadaan tanah adalah 3 (tiga) hari kerja setelah tanggal penetapan lokasi harus sudah diumumkan. Pengajuan pelaksanaan pengadaan tanah oleh PT. PLN kepada Kantor wilayah BPN Provinsi Jawa Tengah yang belum habis jangka waktu pengumumannya. Hal tersebut disamping belum dipatuhinya jadwal waktu yang sesuai denga UU pengadaan tanah jo Perpres nomor 71 tahun 2012 juga berdampak pada jangka waktu kegiatan pelaksanaan lainnya di dalam pengadaan tanah untuk kepentingan umum di Kabupaten Cilacap.

Kendala normatif yang dihadapi adalah pertama belum diaturnya nilai ganti kerugian secara immateril. Kedua adalah jangka waktu bentuk ganti kerugian selain berupa uang yaitu tanah pengganti, pemukiman kembali yang begitu lama yaitu 6 (enam) sampai dengan 12 (dua belas) bulan. Ketiga adalah harus adanya jaminan dari pemilik tanah bahwa sertipikat atau tanda bukti hak yang diserahkan kepada instansi yang membutuhkan tanah dalam pengadaan tanah tidak akan diganggu gugat oleh pihak lain. Keempat adalah mekanisme penitipan ganti kerugian ke pengadilan negeri yang belum diatur dalam undang-undang pengadaan tanah yaitu dalam hal masih adanya pihak yang berhak belum sepakat dengan bentuk ganti kerugian yang ditawarkan oleh instansi yang membutuhkan tanah, maka ganti kerugian dititipkan ke pengadilan negeri dan bersamaan dengan itu maka kepemilikan atau hak atas tanah dari pihak yang berhak menjadi hapus dan alat bukti haknya dinyatakan tidak berlaku dan tanahnya menjadi tanah yang dikuasai langsung oleh negara.

\section{Saran}

Sebaiknya pemerintah perlu merevisi UU Pengadaan Tanah dan peraturan pelaksanaannya. Revisi tersebut meliputi:
a. Memasukan nilai ganti kerugian immateril.
b. Memasukan mekanisme penitipan ganti kerugian di pengadilan negeri.

\section{DAFTAR PUSTAKA}

Abdurrahman. 1983. Masalah Hak-Hak Atas Tanah dan Pembebasan Tanah di Indonesia. cet. 2. Alumni. Bandung.;

Hanintejo Sumitro,Ronny, 1988. Metode Penelitian Hukum. PT. Alumni, Bandung;

Hardjosoemantri, Koesnadi. 1999. Hukum Tata Lingkungan. Gajah Mada University Press. Yogyakarta;

Harsono. Boedi, 1994. Hukum Tanah, Djambatan, Jakarta;

Rubaie, Achmad. 2007. Hukum Pengadaan Tanah untuk Kepentingan Umum, Bayumedia Publishing, Malang;

Ruchiyat, Eddy. 1999. Politik Pertanahan Nasional sampai Orde Reformasi, PT. Alumni, Bandung; 
Suratman dan Dillah Philips, 2013. Metode Penelitian Hukum, Alfabeta, Bandun;

S.W. Sumarjono, Maria.2001. Kebijakan Pertanahan antara Regulasi dan Implementasi, Buku Kompas, Jakarta;

Sutedi, Adrian, 2008, Implementasi Prinsip Kepentingan Umum dalam Pengadaan Tanah Untuk Pembangunan, Sinar Grafika, Jakarta;

Wayan, Suandra, I. 1994. Hukum Pertanahan Indonesia, PT.Rineke Cipta, Jakarta . 